\title{
COVID-19 and Its Impact on Men's Sexual and Reproductive Health: A Review
}

\author{
Maria A Grácio* \\ Institute of Hygiene and Tropical Medicine, New University of Lisbon, Lisbon, Portugal \\ ${ }^{\star}$ Corresponding author: Maria A Grácio, Institute of Hygiene and Tropical Medicine, New University of Lisbon, Rua da Junqueira 100, 1348-008 Lisbon, Portugal
}

Received: August 09, 2021; Accepted: August 16, 2021; Published: August 23, 2021

\begin{abstract}
Considering the medical, economic and social importance of the COVID-19 disease occurring in men, we have as objectives in this manuscript to contribute to knowledge of the impact of this viral disease on men's sexual and reproductive health.
\end{abstract}

Keywords: Coronavirus, Coronavirus, COVID-19, SARS Coronavirus 2, SARS-Co2, Men's sexual and reproductive health

\section{Introduction}

COVID-19 is a viral disease whose causative agent was identified in Wuhan-China, as a novel coronavirus, severe acute respiratory syndrome coronavirus2 (SARS-CoV-2) [1]. After, 15 April 2020, COVID-19 has caused more than two million confirmed cases and more than 128,000 deaths globally, including 82,295 confirmed cases and 3342 deaths in China [2]. The Chinese government has locked Wuhan city, since 23 January 2020, and implemented a series of social distancing measures such as: strict traffic restrictions, prohibition of social gatherings; and closure of residential communities [3]. In [4] the authors have referred to "the epidemiological data in China that have shown that most cases had mild symptoms, with an overall case fatality rate of 2,3\%. Although, SARS-CoV-2 appears_to be less virulent than 2 previous zoonotic coronavirus, SARS-CoV and Middle East respiratory syndrome coronavirus (MERS-CoV), it is far more efficient in transmitting between people in close contact".

In [5] we found a review on "Male genital damage in COVID-19 patients", that, in our opinion, is an excellent review with interest for scientists and public in general. In this review, where the authors have indicated "over the past few weeks, we have observed increasing concern about the possible impact of coronavirus disease 2019 (COVID-19) which is caused by severe acute respiratory syndrome coronavirus 2 (SARS-CoV.2 virus) on male fertility. Thus, we examined available data including published and unpublished articles to assess the potential risk of COVID-19 in particular on the male reproductive system. "We emphasize that the authors have concluded: "all preliminary findings mentioned suggest that COVID-19 could impact men's reproductive health inducing spermatogenic failure. In conclusion, even though it seems to us that it is premature to make definitive conclusions at present, this should alert to the possible impact of COVID-19 on the male reproductive system. Further investigations of the potential male genital damage are warranted."

In [6] we have a review on male sexual and reproductive health in the wake of COVID-19 outbreak that, in our opinion, is an excellent publication with interest for scientists and the public in general.

The authors have made "a literature research on the possible mechanisms involved in the development of Erectile Dysfunction (ED) in COVID-19 survivors was performed." In our results have indicated that: (i) "COVID-19 might exacerbate cardiovascular conditions; therefore, further increasing of risk of ED; (ii) testicular function in COVID-19 patients requires careful investigations for the unclear association with testosterone deficiency and the possible consequences for reproductive health".

The authors have concluded that "COVID-19 survivors might develop sexual and reproductive health tissue. Andrological assessment and tailored treatments should be considered in the follow-up.

\section{Final Conclusions}

1. We think that it was here demonstrated that COVID-19, has an impact on the men's sexual and reproductive health.

2. We hope that with the attention that is being given to this viral disease is possible, in a short/medium time, to obtain more knowledge, concerning the virus, the treatment and the vaccines, so that with this knowledge is possible a control of all viral variants circulating in the world.

3. To combat COVID-19, it is necessary:

i) To have persons specialized for the different types of combat;

ii) The collaboration between countries at world level;(iii) The collaboration of the person, in general, for the execution of the rules established by health services of their countries;

iii) The collaboration between different governmental services;

iv) The collaboration between different community services such as town halls and, hospitals. 


\section{References}

1. Archived: WHO Timeline - COVID-19, 27 April 2020- www.who.int World Health Organization. Novel coronavirus - China. Geneva, Switzerland: Word Health Organization httpps.//www.who.int/csr/don/12-january-2020-novelcoronavirus-china/en/.[2020-01-12]

2. COVID-19 - Global Health, COVID-19: What you need to know about the coronavirus pandemic in 15 April. www.weform.org

3. Wuham lockdown: a year of Chinas fight against the COVID pandemic - 22 January, Corona virus pandemic www.bbc.com

4. World Health Organization. The epidemiological characteristics of an outbreak of 2019 novel coronavirus disease (COVID-19)- China 2020. And www.ourphn.org.au
5. Kharbach Y, Khallouk A, Malegenital damage in COVID-19 patients: Are available data relevant?, Asian Journalof Urology, https://doi.org/10.1016/j.ajur.2020.06.005https:// doi.org/10.1016/j.ajur.2020.06.0052214-3882/a2020 Editorial Office of Asian Journal of Urology. Production and hosting by Elsevier B.V. This is an open access article underthe CC BY-NC-ND license (http://creativecommons.org/licenses/by-ncnd/4.0/).Available online at www.sciencedirect.comScienceDirectjournal homepage: www.elsevier.com/locate/ajurAsian Journal of Urology xxx ( $x x x x) x x x$

6. Sansone A, Mollaioli D, Ciocca G, Limoncin E, Colonnello E, et al. (2021) Addressing male sexual and reproductive health in the wake of COVID-19 outbreak. J Endocrinol Invest 44: 223-231. [crossref] 